\title{
STUDI PENURUNAN KEKERUHAN DENGAN APLIKASI EKSTRAK TAPIOKA SEBAGAI KOAGULAN ALAM PADA PENGOLAHAN AIR BERSIH
}

\section{THE STUDY OF TURBIDITY REMOVAL BY USING TAPIOCA EXTRACT AS NATURAL COAGULANT ON WATER TREATMENT}

\author{
Eka Prihatinningtyas ${ }^{a, *}$ dan Taofik Jasalesmana ${ }^{a}$ \\ a Pusat Penelitian Limnologi-LIPI; Kompleks LIPI Cibinong, \\ Jalan Raya Bogor, Km. 46, Cibinong 16911; Telp. 021 8757071; Faks. 021 8757076; \\ *Email :ekap@limnologi.lipi.go.id
}

Diterima : $12-12-2020$

Revisi : 08-06-2021

Disetujui : 15-06-2021

\begin{abstract}
ABSTRAK
Salah satu proses penting dalam pengolahan air bersih adalah koagulasi. Keberhasilan proses tersebut sangat ditentukan oleh pemilihan koagulan dan penentuan dosis yang optimal. Tepung tapioka dapat digunakan sebagai koagulan alami dalam menurunkan kekeruhan. Pada penelitian ini digunakan limbah artifisial yang terbuat dari kaolin. Kaolin digunakan sebagai sumber pengkeruh yang merepresentasikan sumber air baku dalam pengolahan air bersih. Uji statistik ANOVA telah dilakukan untuk mengetahui pengaruh pH (tanpa variasi dosis koagulan), dosis koagulan (tanpa variasi $\mathrm{pH}$ ) dan kombinasi keduanya terhadap proses koagulasi. Proses koagulasi dilakukan pada kekeruhan 150 NTU dengan variasi dosis koagulan $(5,10,15,20,40,60,80$ dan 100 ppm) dan 4 variasi pH (3,5,7 dan 9). Hasil penelitian menunjukkan bahwa nilai $p$ value untuk $\mathrm{pH}$, dosis koagulan dan kombinasi keduanya masing-masing sebesar 0,00 . Nilai $p$ value kurang dari 0,05 mengindikasikan bahwa $\mathrm{pH}$, dosis koagulan dan kombinasi keduanya berpengaruh signifikan dalam menurunkan kekeruhan. Fenomena tersebut dibuktikan dengan adanya kenaikan nilai konduktivitas. Kenaikan nilai konduktivitas mengindikasikan terjadinya kenaikan gaya tarik-menarik antara ion-ion koagulan dan kaolin.
\end{abstract}

Kata kunci : koagulan alami, konduktivitas, tepung tapioka

\begin{abstract}
Coagulation is the main process in water and wastewater treatment. The efficiency of coagulation is largely determined by the selection of coagulants and the addition of optimum coagulant dose. Tapioca flour can be used as a natural coagulant to remove the turbidity of artificial raw water made from kaolin. Kaolin is used as a source of turbidity which represents the raw water in water treatment. ANOVA analysis was conducted to determine the effect of $\mathrm{pH}$ (without variation in coagulant dose), coagulant dose (without $\mathrm{pH}$ variation), and the combination of both on the coagulation process. The coagulation process was carried out at 150 NTU turbidity with various coagulant doses $(5,10,15,20$, $40,60,80$, and $100 \mathrm{ppm})$ and $4 \mathrm{pH}$ variations (3,5,7 and 9). The results showed that the $p$-value for $\mathrm{pH}$, coagulant dose, and the combination of both were 0.000 respectively. A p-value of less than 0.05 indicates that $\mathrm{pH}$, coagulant dose, and the combination of both have a significant effect in reducing turbidity. This phenomenon is evidenced by an increase in the value of the conductivity. The increase in the value of the conductivity indicates an increase in the attractive forces between the coagulant ions and kaolin.
\end{abstract}

Keywords: conductivity, natural coagulant, tapioca flour 


\section{PENDAHULUAN}

ekeruhan merupakan salah satu parameter wajib yang terdapat dalam standar
baku mutu air minum (Permenkes RI, 2010). Selain karena alasan estetika,
kekeruhan menunjukkan keberadaan partikel padatan dalam air bersih (Sawyer et al., 2003). Salah satu teknologi yang dapat digunakan untuk menyisihkan partikel dalam air adalah koagulasi, flokulasi dan sedimentasi. Koagulasi merupakan tahap pertama dari proses agregasi partikel yang dilakukan dengan menambahkan koagulan. Penambahan koagulan berfungsi untuk mempercepat proses pengikatan partikel dan pengendapannya.

Koagulan yang umum digunakan adalah koagulan kimia seperti aluminium sulfat (alum) dan garam besi (Eckenfelder, 2000). Keunggulan koagulan kimia adalah harga relatif murah dan mudah diperoleh. Namun, penggunaan alum pada umumnya akan menghasilkan jumlah lumpur yang banyak (Bhuptawat et al., 2007). Kandungan aluminium dalam lumpur akan mencemari lingkungan. Selain itu, keberadaan aluminium dalam air minum dapat memicu timbulnya penyakit Alzheimer (Crisponi et al., 2011).

Material organik dari hewan dan tumbuhan telah dikembangkan dan digunakan sebagai koagulan alami guna mengurangi dampak negatif penggunaan koagulan kimia. Moringa oleifera (kelor) adalah jenis tumbuhan yang banyak digunakan sebagai koagulan alami, baik dalam pengolahan air bersih maupun limbah cair (Shan et al., 2017; Camacho et al., 2017; Salazar Gámez et al., 2015; Dalvand et al., 2016). Beberapa material organik yang telah teruji sebagai koagulan adalah pati (Choy et al., 2014), tannin (Beltrán-Heredia et al., 2011; (Barrado-Moreno et al., 2016), kacang-kacangan (Antov et al., 2010; Šćiban et al., 2009) dan chitosan (Kumar \& Quaff, 2018). Koagulan kimia pada umumnya mengandung protein (Srawaili, 2008;(Antov et al., 2010) dan bersifat polielektrolit (Reynolds, T. D. , Richards, 1996). Larutan polielektrolit mudah terdisosiasi dalam air dan bermuatan listrik. Oleh karena itu, penambahan koagulan dalam proses koagulasi dapat mengurangi atau mengeliminasi kekuatan inter partikulat. Kekuatan inter partikulat berfungsi untuk menjaga stabilitas partikel. Proses destabilisasi partikel merupakan kunci utama dalam proses koagulasi (Kawamura, 1991).

Penelitian ini menggunakan tepung tapioka sebagai koagulan alami. Saat ini, pemanfaatan tepung tapioka masih terbatas pada industri pangan, kertas dan farmasi.

Parameter yang memengaruhi proses koagulasi adalah $\mathrm{pH}$ dan dosis koagulan. Penelitian ini bertujuan untuk mengetahui pengaruh $\mathrm{pH}$ dan dosis koagulan terhadap penurunan kekeruhan pada proses koagulasi. Uji ANOVA (analysis of variance) digunakan untuk menguji perbedaan mean (rata-rata) data lebih dari dua kelompok.

\section{METODE PENELITIAN Alat dan Bahan}

Peralatan yang digunakan dalam penelitian ini antara lain jar test SW1, turbidimeter Lovibond, konduktometer Metrohm, $\mathrm{pH}$ meter, centrifuge, neraca digital dan alat gelas, dan bahan-bahan yang digunakan dalam penelitian ini adalah tepung tapioka, kaolin dan $\mathrm{NaCl} 1$ M.

\section{Metode \\ Aktivasi Koagulan Alami}

Aktivasi komponen aktif dalam koagulan alami dilakukan dengan cara ekstraksi. Sebanyak 5 gram tepung tapioka dilarutkan dalam $100 \mathrm{~mL}$ larutan $\mathrm{NaCl} 1 \mathrm{M}$ kemudian diaduk selama 30 menit menggunakan stirrer pada suhu ruang. Proses pemisahan dilakukan dengan sentrifugasi pada kecepatan 8000 rpm selama 10 menit. Supernatan yang diperoleh selanjutnya dinamakan ekstrak tapioca (Antov et al., 2010). 


\section{Persiapan Larutan Induk Limbah}

Pada penelitian ini digunakan limbah artifisial. Kaolin digunakan sebagai sumber kekeruhan dalam limbah artifisial. Pembuatan limbah artifisial dilakukan dengan cara melarutkan 1 gram kaolin dalam $1000 \mathrm{~mL}$ air kran dengan menggunakan stirrer. Proses homogenisasi dilakukan selama 1 jam. Larutan tersebut didiamkan selama 24 jam dan selanjutnya dinamakan larutan induk dengan kekeruhan sebesar 1000 NTU (Šćiban et al., 2009).

Proses pengenceran dilakukan untuk memperoleh limbah artifisial dengan kekeruhan tertentu. Kekeruhan 150 NTU diperoleh dengan cara melarutkan $150 \mathrm{~mL}$ larutan induk ke dalam $850 \mathrm{~mL}$ air kran. Proses pengenceran dilakukan sesaat sebelum jar test koagulasi dilakukan.

\section{Jar test}

Jar test merupakan simulasi proses koagulasi flokulasi pada skala laboratorium. Sebanyak $1000 \mathrm{~mL}$ sampel air limbah artifisial dimasukkan ke dalam gelas beaker kemudian dilakukan pengkondisian $\mathrm{pH}$. Sebanyak $0,1 \mathrm{~mL}$ koagulan ditambahkan ke dalam limbah artifisial. Nilai tersebut mewakili dosis sebesar $5 \mathrm{ppm}$. Hal yang sama dilakukan untuk variasi dosis yang lain $(10,15,20,40,60,80$ dan 100 ppm), seperti tercantum dalam Tabel 1. Pengkondisian $\mathrm{pH}$ dilakukan dengan menambahkan larutan $\mathrm{HCl}$ encer untuk menurunkan nilai $\mathrm{pH}$ sedangkan larutan $\mathrm{NaOH}$ encer digunakan untuk menaikkan nilai $\mathrm{pH}$. Penambahan larutan $\mathrm{HCl}$ encer dan $\mathrm{NaOH}$ encer dilakukan dengan menggunakan pipet tetes sampai mendapatkan nilai $\mathrm{pH}$ yang diinginkan.

Limbah artifisial yang telah ditambah koagulan dan dikondisikan $\mathrm{pH}$ selanjutnya diaduk dengan kecepatan tinggi (200 rpm) selama 1 menit, dilanjutkan dengan kecepatan rendah (60 rpm) selama 15 menit. Tahap berikutnya adalah sedimentasi atau pengendapan. Proses sedimentasi berlangsung selama 30 menit. Supernatan atau cairan yang lebih jernih akan terbentuk di bagian atas larutan. Supernatan diambil dengan menggunakan pipet volume dan diukur kekeruhan akhirnya. Pengukuran konduktivitas juga dilakukan sebelum dan setelah jar test. Setiap percobaan dilakukan dengan dua kali ulangan.

Efisiensi koagulasi dihitung dengan membandingkan jumlah penurunan kekeruhan dengan kekeruhan awal. Pada penelitian ini juga dianalisis pengaruh $\mathrm{pH}$ dan dosis koagulan terhadap proses koagulasi dengan menggunakan metode statistik Analysis of Variance (ANOVA). Perhitungan ANOVA dilakukan dengan menggunakan software MINITAB 17.

Tabel 1. Kombinasi pH dan dosis percobaan

\begin{tabular}{rccccccccccc}
\hline No & $\mathrm{pH}$ & $\begin{array}{l}\text { Dosis } \\
(\mathrm{ppm})\end{array}$ & No & $\mathrm{pH}$ & $\begin{array}{l}\text { Dosis } \\
(\mathrm{ppm})\end{array}$ & No & $\mathrm{pH}$ & $\begin{array}{l}\text { Dosis } \\
(\mathrm{ppm})\end{array}$ & No & $\mathrm{pH}$ & $\begin{array}{c}\text { Dosis } \\
(\mathrm{ppm})\end{array}$ \\
\hline 1 & 3 & 5 & 17 & 5 & 5 & 33 & 7 & 5 & 49 & 9 & 5 \\
2 & 3 & 5 & 18 & 5 & 5 & 34 & 7 & 5 & 50 & 9 & 5 \\
3 & 3 & 10 & 19 & 5 & 10 & 35 & 7 & 10 & 51 & 9 & 10 \\
4 & 3 & 10 & 20 & 5 & 10 & 36 & 7 & 10 & 52 & 9 & 10 \\
5 & 3 & 15 & 21 & 5 & 15 & 37 & 7 & 15 & 53 & 9 & 15 \\
6 & 3 & 15 & 22 & 5 & 15 & 38 & 7 & 15 & 54 & 9 & 15 \\
7 & 3 & 20 & 23 & 5 & 20 & 39 & 7 & 20 & 55 & 9 & 20 \\
8 & 3 & 20 & 24 & 5 & 20 & 40 & 7 & 20 & 56 & 9 & 20 \\
9 & 3 & 40 & 25 & 5 & 40 & 41 & 7 & 40 & 57 & 9 & 40 \\
10 & 3 & 40 & 26 & 5 & 40 & 42 & 7 & 40 & 58 & 9 & 40
\end{tabular}




\begin{tabular}{cccccccccccc}
11 & 3 & 60 & 27 & 5 & 60 & 43 & 7 & 60 & 59 & 9 & 60 \\
12 & 3 & 60 & 28 & 5 & 60 & 44 & 7 & 60 & 60 & 9 & 60 \\
13 & 3 & 80 & 29 & 5 & 80 & 45 & 7 & 80 & 61 & 9 & 80 \\
14 & 3 & 80 & 30 & 5 & 80 & 46 & 7 & 80 & 62 & 9 & 80 \\
15 & 3 & 100 & 31 & 5 & 100 & 47 & 7 & 100 & 63 & 9 & 100 \\
16 & 3 & 100 & 32 & 5 & 100 & 48 & 7 & 100 & 64 & 9 & 100 \\
\hline
\end{tabular}

\section{HASIL DAN PEMBAHASAN}

\section{Pengaruh pH dan Dosis Koagulan terhadap Penurunan Kekeruhan}

Dosis koagulan dan $\mathrm{pH}$ merupakan kondisi operasi proses koagulasi yang dominan. Limbah artifisial memiliki kekeruhan awal sebesar 150 NTU. Gambar 1 menunjukkan hasil pengukuran kekeruhan akhir setelah penambahan dosis koagulan dan variasi $\mathrm{pH}$. Besarnya penurunan kekeruhan bervariasi pada setiap $\mathrm{pH}$ yang digunakan. Proses koagulasi yang berlangsung pada kondisi yang sangat asam ( $\mathrm{pH}=3$ ) menghasilkan air produksi dengan kekeruhan air yang rendah. Kondisi yang sama juga terlihat pada proses koagulasi yang berlangsung pada $\mathrm{pH}$ 5. Sedangkan koagulasi pada $\mathrm{pH} 7$ akan menghasilkan jumlah penurunan kekeruhan lebih cenderung kecil dibandingkan pada $\mathrm{pH}$ 9, kecuali pada dosis 60 dan 80 ppm.

Salah satu parameter yang mempengaruhi koagulasi adalah $\mathrm{pH}$. Kondisi $\mathrm{pH}$ berkaitan dengan kestabilan dan dispersi kaolin (Lin \& Lee, 2007). Hal ini disebabkan oleh adanya ionisasi pada permukaan atau adsorpsi ion dari larutan pendispersinya yang kemudian akan mengakibatkan lemahnya gaya elektrostatik kaolin (Reynolds, T. D. , Richards, 1996). Melemahnya gaya elektrostatik pada kaolin akan mengakibatkan mudahnya kaolin terdispersi dan berikatan dengan molekul lain.

Proses koagulasi sangat dipengaruhi oleh kadar keasaman. Berdasarkan Gambar 1, dapat dikatakan bahwa nilai penurunan kekeruhan akan bertambah pada kondisi yang semakin asam. Pada kondisi sangat asam, kaolin mengadsorpsi ion $\mathrm{H}^{+}$dari asam yang ditambahkan. Adsorpsi ini menyebabkan kaolin bermuatan positif. Secara teori, ekstrak tapioka yang digunakan sebagai koagulan alami mengandung gugus karboksil (- $\mathrm{COOH})$, hidroksil $(-\mathrm{OH})$ dan amida $\left(-\mathrm{CONH}_{2}\right)$. Ketiga gugus tersebut adalah penyusun senyawa polimer organik (protein) (Antov et al., 2010; Widjanarko et al., 2011). Protein bersifat amfoter karena memiliki dua muatan yang berbeda. Gugus karboksil mengakibatkan koagulan bermuatan positif, sedangkan gugus amida dan hidroksil menyumbangkan muatan negatif dalam koagulan.

Hadirnya koagulan yang memiliki dua gugus fungsi bermuatan negatif ini, yaitu amida dan hidroksil, menyebabkan terjadinya reaksi protonasi antara ion $\mathrm{H}^{+}$pada permukaan kaolin dengan gugus fungsi bermuatan negatif pada koagulan. Ikatan ini akan mengurangi atau menetralkan muatan pada permukaan kaolin, sehingga gaya elektrostatik pada kaolin menurun. Penurunan gaya elektrostatik ini menyebabkan molekul kaolin terdispersi, kemudian membentuk ikatan dengan koagulan sampai terbentuk molekul yang lebih berat sehingga mudah terendapkan oleh gaya gravitasi (Srawaili, 2008). Hasil yang sama juga diperoleh oleh (Patel \& Vashi, 2012) yang menggunakan chitosan, jagung dan Moringa oleifera sebagai koagulan alami.

Berdasarkan hasil pengukuran kekeruhan akhir, terlihat bahwa besarnya penurunan kekeruhan juga sangat dipengaruhi oleh dosis koagulan. Perubahan penurunan kekeruhan terhadap variasi dosis koagulan bervariasi di setiap $\mathrm{pH}$ yang digunakan. Perubahan paling besar terjadi pada $\mathrm{pH} 7$, dengan koefisien regresi penurunan kekeruhan sebesar 0,358. Sedangkan perubahan terkecil terjadi pada larutan dengan $\mathrm{pH} 9$, yaitu sebesar 0,066. Besarnya perubahan penurunan pada pH 5 dan 9 berada di antara pH 3 dan 7. 
Penambahan dosis koagulan artinya memberikan sejumlah muatan ke dalam kaolin. Semakin besar dosis koagulan yang ditambahkan maka semakin besar pula muatan yang diberikan. Hal ini menyebabkan terjadinya reaksi antara koagulan dan kaolin yang berakibat pada

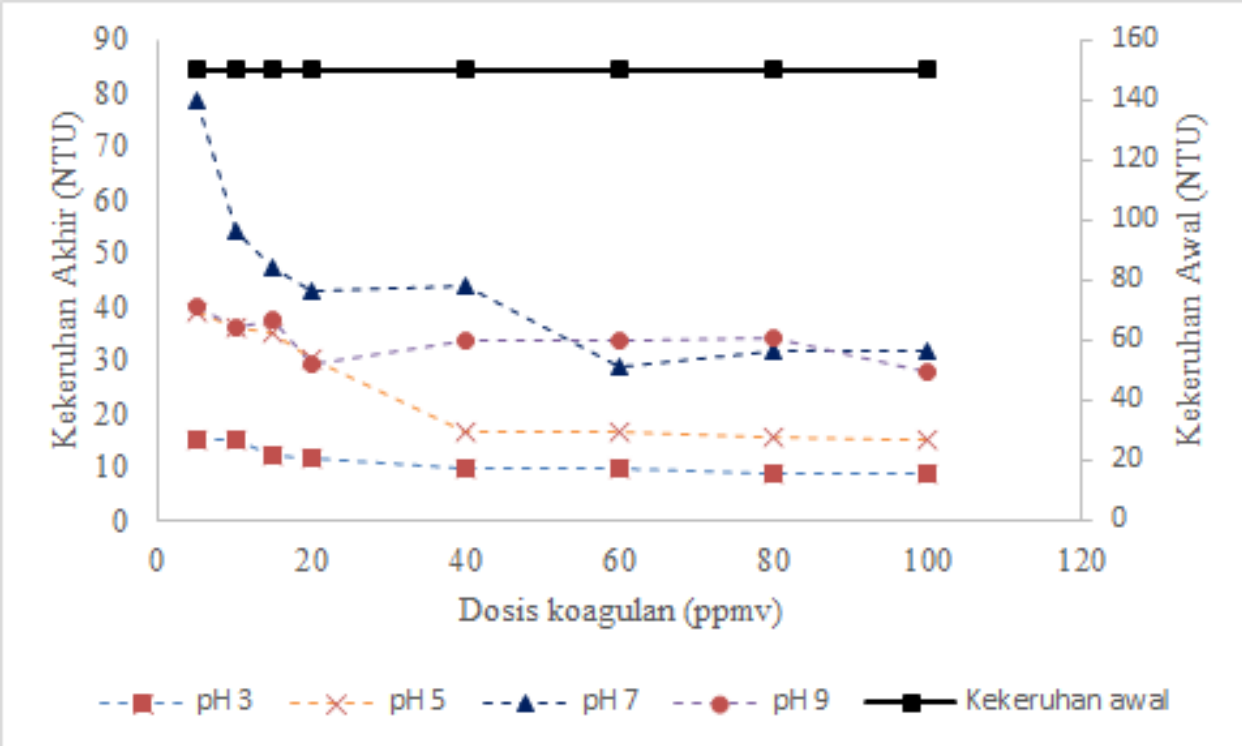

cepatnya penurunan kekeruhan. Besarnya pengaruh perubahan dosis koagulan pada penurunan kekeruhan di $\mathrm{pH} 7$ dapat dijelaskan karena pada $\mathrm{pH}$ netral kaolin tidak terdispersi seperti pada $\mathrm{pH}$ asam, sehingga satu-satunya yang bekerja untuk menarik molekul kaolin hanya molekul koagulan.

Gambar 1. Kekeruhan akhir pada proses koagulasi. Koefisien regresi penurunan kekeruhan (b), pada $\mathrm{pH} 3, \mathrm{~b}=0,066$, pada $\mathrm{pH} 5, \mathrm{~b}=0,266$, pada $\mathrm{pH} \mathrm{7,} \mathrm{b}=0,358$, dan pada $\mathrm{pH} 9, \mathrm{~b}=$ 0,0744 .

Efisiensi proses koagulasi digunakan untuk melihat jumlah penurunan kekeruhan hasil dari proses koagulasi. Besarnya nilai efisiensi penyisihan kekeruhan dapat dilihat pada Gambar 2. Efisiensi penyisihan kekeruhan paling tinggi pada setiap variasi dosis yang digunakan secara umum berurutan terjadi pada $\mathrm{pH}$ 3, 5, 7 dan 9. Perubahan dosis terlihat nyata mempengaruhi nilai efisiensi terjadi pada $\mathrm{pH} 5$ dan $\mathrm{pH} 7$ terutama pada variasi dosis kurang dari 60 ppm. Sedangkan perubahan dosis pada $\mathrm{pH} 3$ dan 9 cenderung tidak merubah nilai efisiensi penyisihan kekeruhan. Secara umum penyisihan kekeruhan paling optimum terjadi pada kondisi $\mathrm{pH} 3$. 
Gambar 2. Efisiensi penurunan kekeruhan larutan pada variasi pH dan dosis koagulan

Mekanisme koagulasi yang terjadi pada $\mathrm{pH} 3$ didominasi oleh proses dispersi oleh asam. Kondisi pH 3 masih berada di bawah titik isoelektrik, sehingga gugus - $\mathrm{COOH}$ tidak terionisasi. Akibat perbedaan muatan antara koloid dan koagulan maka akan terbentuk ikatan ion atau hidrogen. Adanya ikatan ion atau hidrogen ini akan mengurangi atau menetralkan muatan pada permuakaan partikel koloid.

Efisiensi koagulasi pada $\mathrm{pH} 5$ lebih tinggi dibandingkan dengan $\mathrm{pH} 7$ dan 9. Hal ini terjadi karena titik isoelektrik protein tercapai pada pH 5 (Antov et al., 2010). Pada titik isoelektrik, jumlah penambahan proton (ion positif) akan sama dengan pengurangan muatan, sehingga menghasilkan muatan sebesar nol. Koagulasi yang berlangsung pada titik isoelektrik akan memberikan hasil yang optimum.

Pada kondisi di atas titik isoelektrik ( $\mathrm{pH} 7$ dan 9), kaolin akan bermuatan negatif. Gugus karboksil $(-\mathrm{COOH})$ akan terionisasi menjadi (- $\left.\mathrm{COO}^{-}\right)$. Proses penurunan kekeruhan masih terjadi pada kondisi tersebut karena gugus (- $\left.\mathrm{COO}^{-}\right)$. Pada kondisi tersebut, gugus amida dan hidroksil tidak ikut berperan. Akibatnya efisiensi koagulasi yang diperoleh lebih rendah jika dibandingkan dengan koagulasi yang berlangsung pada pH 3 dan 5 .

Penambahan dosis koagulan yang berlebih akan memberikan efisiensi penurunan kekeruhan yang tidak berbeda jauh karena akan terjadi kegagalan pembentukan flok. Mekanisme yang terjadi adalah polimer-polimer dalam koagulan alami akan menutupi seluruh permukaan partikel koloid sehingga tidak ada tempat untuk rantai akhir menempel dan proses flokulasi tidak terjadi. Keadaan ini dapat mengakibatkan partikel koloid akan kembali stabil atau tidak dapat bergabung dengan partikel lain (Srawaili, 2008). Oleh karena itu, efisiensi koagulasi pada penambahan dosis lebih dari 40 ppm cenderung stabil.

\section{Pengaruh Koagulasi Terhadap Konduktivitas}

Selain menyebabkan kekeruhan, padatan terlarut dalam limbah juga mengandung mineral yang dapat terionisasi. Ion-ion tersebut mampu menghantarkan listrik di dalam air. Pengukuran konduktivitas (daya hantar listrik) bertujuan untuk memprediksi jumlah ion dan aktivitas yang terjadi selama proses koagulasi. Konduktivitas kaolin sebelum perlakuan (K_awal) 201 Hasil

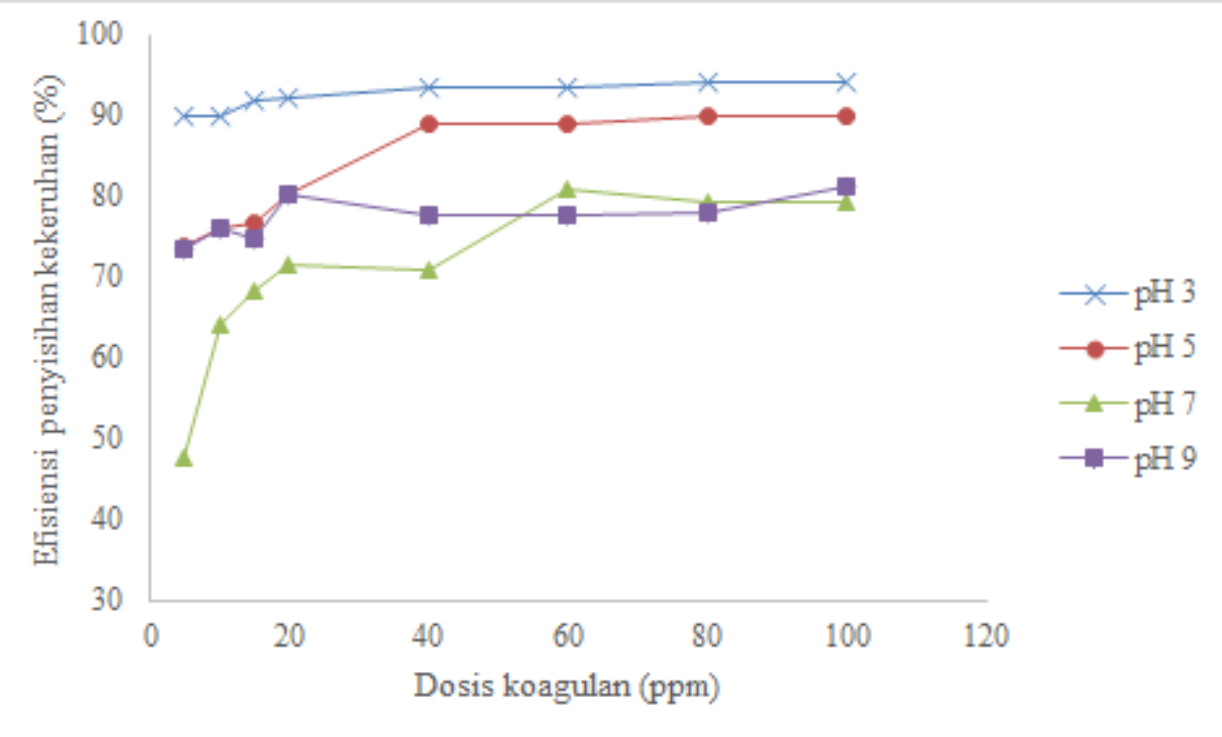
sebesar $\mu \mathrm{S} / \mathrm{cm}$. 
pengukuran konduktivitas sebelum dan setelah proses koagulasi dapat dilihat pada Gambar 3 berikut.

Gambar 3. Hasil pengukuran konduktivitas

Secara umum, penambahan dosis koagulan akan meningkatkan nilai konduktivitas. Koagulan merupakan larutan polielektrolit dan bermuatan ion. Oleh karena itu, penambahan koagulan dalam proses koagulasi akan meningkatkan jumlah ion di dalam koloid. Puncak kenaikan nilai konduktivitas terjadi ketika penggunaan dosis koagulan sebesar 20 ppm. Penambahan dosis koagulan lebih dari 20 ppm akan menyebabkan konsentrasi larutan menjadi semakin pekat. Hal ini mengakibatkan ion-ion tidak dapat bergerak secara bebas. Pada konsentrasi yang lebih encer, pergerakan ion dapat berlangsung secara bebas sehingga terjadi kenaikan konduktivitas. Teori Debye-Huckel menjelaskan bahwa efek elektroforetik dan relaksasi terjadi pada proses koagulasi dengan dosis koagulan tinggi. Kedua efek tersebut menyebabkan mobilitas ion seolah-olah ditarik oleh ion berlawanan yang terletak di belakang ion tersebut. Hal ini akan menghambat mobilitas ion yang sesungguhnya (Febriyanto, 2019).

Faktor $\mathrm{pH}$ sangat mempengaruhi besarnya nilai konduktivitas. Jumlah ion $\mathrm{H}^{+}$akan meningkat jika kondisi larutan semakin asam, sedangkan jumlah ion $\mathrm{OH}^{-}$akan bertambah jika kondisi larutan semakin basa. Kedua kondisi tersebut sama-sama akan meningkatkan nilai konduktivitas larutan. Pada kondisi asam, kenaikan nilai konduktivitas cukup signifikan. Hal ini mengindikasikan bahwa ion $\mathrm{H}^{+}$lebih atraktif dalam berikatan dengan ion-ion koagulan. Pada kondisi netral $(\mathrm{pH}=7)$, jumlah ion $\mathrm{H}^{+}$dan ion $\mathrm{OH}^{-}$akan berada dalam jumlah yang seimbang. Pada kondisi tersebut, fenomena yang terjadi adalah ikatan antara ion $\mathrm{H}^{+}$dan ion $\mathrm{OH}^{-}$. Hal ini menyebabkan ion-ion yang dapat berikatan dengan senyawa polielektrolit dari koagulan alami menjadi berkurang. Akibatnya nilai konduktivitas mengalami penurunan. Pada kondisi tersebut, nilai konduktivitas akan berada pada titik terendah.

\section{Uji Statistik Pengaruh Dosis Koagulan dan pH terhadap Penurunan Kekeruhan}

Uji statistik dengan menggunakan ANOVA telah dilakukan untuk menguji pengaruh dosis koagulan dan $\mathrm{pH}$ terhadap proses koagulasi oleh ekstrak tapioka sebagai koagulan alami limbah yang dari kaolin. ANOVA dilihat

Tabel 2.

Tabel 2. Uji pengaruh dosis penurunan

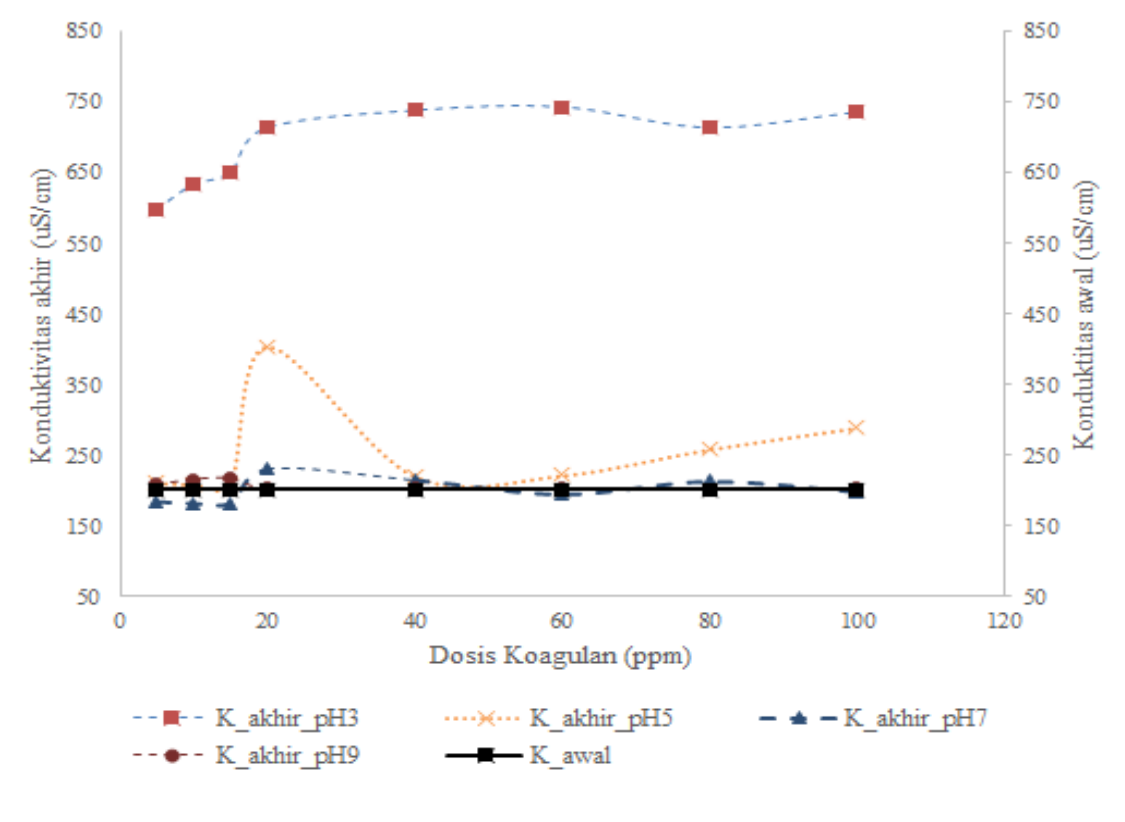

terhadap artifisial terbuat larutan Hasil uji dapat pada

ANOVA

$\mathrm{pH}$ dan terhadap kekeruhan

Parameter P-Value




\begin{tabular}{ll}
\hline $\mathrm{pH}$ & 0,000 \\
Dosis & 0,000 \\
pH vs Dosis & 0,000 \\
\hline
\end{tabular}

Hasil uji ANOVA menunjukkan bahwa nilai $p$-value untuk $\mathrm{pH}$, dosis koagulan dan pengaruh keduanya sebesar 0,000. Nilai $p$-value terhitung lebih kecil dari 0,05. Hal ini menunjukkan bahwa pengaruh $\mathrm{pH}$ (tanpa variasi dosis koagulan), dosis koagulan (tanpa variasi $\mathrm{pH}$ ), dan kombinasi keduanya berpengaruh signifikan dalam menurunkan kekeruhan.

\section{KESIMPULAN}

Tepung tapioka dapat dimanfaatkan sebagai koagulan alami untuk menurunkan kekeruhan pada proses pengolahan air bersih. Proses koagulasi dipengaruhi oleh $\mathrm{pH}$ dan dosis koagulan. Kombinasi penambahan dosis koagulan sebesar $40 \mathrm{ppm}$ dan pH 5 memberikan nilai efisiensi penurunan kekeruhan paling optimum. Berdasarkan hasil uji statistik dengan menggunakan ANOVA, pH (tanpa variasi dosis koagulan), dosis koagulan (tanpa variasi $\mathrm{pH}$ ) dan kombinasi keduanya sangat mempengaruhi proses koagulasi. Hal ini dapat dilihat dari nilai $p$-value sebesar 0,00 atau lebih kecil dari 0,05. Penambahan dosis koagulan dan pengaturan $\mathrm{pH}$ mempengaruhi jumlah muatan yang berinteraksi dengan permukaan luar kaolin. Konduktivitas mengindikasikan aktivitas interaksi ion-ion bermuatan antara koagulan dan kaolin.

\section{DAFTAR PUSTAKA}

Antov, M. G., Šćiban, M. B., \& Petrović, N. J. (2010). Proteins from common bean (Phaseolus vulgaris) seed as a natural coagulant for potential application in water turbidity removal. Bioresource Technology, 101(7), 2167-2172. https://doi.org/10.1016/j.biortech.2009.11.020

Barrado-Moreno, M. M., Beltrán-Heredia, J., \& Martín-Gallardo, J. (2016). Removal of Oocystis algae from freshwater by means of tannin-based coagulant. Journal of Applied Phycology, 28(3), 1589-1595. https://doi.org/10.1007/s10811-015-0718-y

Beltrán-Heredia, J., Sánchez-Martín, J., \& Dávila-Acedo, M. A. (2011). Optimization of the synthesis of a new coagulant from a tannin extract. Journal of Hazardous Materials, 186(2-3), 1704-1712. https://doi.org/10.1016/j.jhazmat.2010.12.075

Bhuptawat, H., Folkard, G. K., \& Chaudhari, S. (2007). Innovative physico-chemical treatment of wastewater incorporating Moringa oleifera seed coagulant. Journal of Hazardous Materials. https://doi.org/10.1016/j.jhazmat.2006.08.044

Camacho, F. P., Sousa, V. S., Bergamasco, R., \& Ribau Teixeira, M. (2017). The use of Moringa oleifera as a natural coagulant in surface water treatment. Chemical Engineering Journal, 313, 226-237. https://doi.org/10.1016/j.cej.2016.12.031

Choy, S. Y., Prasad, K. M. N., Wu, T. Y., Raghunandan, M. E., \& Ramanan, R. N. (2014). Utilization of plant-based natural coagulants as future alternatives towards sustainable water clarification. Journal of Environmental Sciences, 26(11), 2178-2189. https://doi.org/10.1016/j.jes.2014.09.024

Crisponi, G., Nurchi, V. M., Faa, G., \& Remelli, M. (2011). Human diseases related to aluminium overload. Monatshefte Fur Chemie, 142(4), 331-340. https://doi.org/10.1007/s00706-011-0474-x

Dalvand, A., Gholibegloo, E., Ganjali, M. R., Golchinpoor, N., Khazaei, M., Kamani, H., Hosseini, S. S., \& Mahvi, A. H. (2016). Comparison of Moringa stenopetala seed extract as a clean coagulant with Alum and Moringa stenopetala-Alum hybrid coagulant to remove direct dye from Textile Wastewater. Environmental Science and Pollution Research, 23(16), 16396-16405. https://doi.org/10.1007/s11356-016-6708-z 
Eckenfelder, W. W. (2000). Industrial Water Pollution Control (3rd ed.). McGraw-Hill.

Febriyanto, R. (2019). Analisis Konduktivitas Pada Produksi Bioflokulan-Dyt Sebagai Pengganti Flokulan Sintesis. Journal of Community Based Environmental Engineering and Management, 3(2), 41. https://doi.org/10.23969/jcbeem.v3i2.1831

Kawamura, S. (1991). Integrated design and operation of water treatment facilities.

Kumar, I., \& Quaff, A. R. (2018). Comparative study on the effectiveness of natural coagulant aids and commercial coagulant: removal of arsenic from water. International Journal of Environmental Science and Technology, 16(10), 5989-5994. https://doi.org/10.1007/s13762-018-1980-8

Lin, S. D., \& Lee, C. C. (2007). Water and Wastewater Calculation Manual (2nd ed.). McGraw-Hill Companies. http://marefateadyan.nashriyat.ir/node/150

Patel, H., \& Vashi, R. T. (2012). Removal of Congo Red dye from its aqueous solution using natural coagulants. Journal of Saudi Chemical Society, 16(2), 131-136. https://doi.org/10.1016/j.jscs.2010.12.003

Permenkes RI. (2010). Peraturan Menteri Kesehatan Republik Indonesia Nomor 492/Menkes/Per/IV/2010 Tentang Persyaratan Kualitas Air Minum. In Peraturan Mentri Kesehatan Republik Indonesia (p. MENKES).

Reynolds, T. D. , Richards, P. (1996). Unit Operations and Processes in Environmental Engineering, (2nd ed.). PWS Publishing Company.

Salazar Gámez, L. L., Luna-delRisco, M., \& Cano, R. E. S. (2015). Comparative study between $M$. oleifera and aluminum sulfate for water treatment: case study Colombia. Environ Monit Assess, 187(10). https://doi.org/10.1007/s10661-015-4793-y

Sawyer, C. N., McCarty, P. L., \& Parkin, G. F. (2003). Chemistry for Environmental Engineering and Science (5th ed.). McGrraw-Hill.

Šćiban, M., Klašnja, M., Antov, M., \& Škrbić, B. (2009). Removal of water turbidity by natural coagulants obtained from chestnut and acorn. In Bioresource Technology (Vol. 100, Issue 24). https://doi.org/10.1016/j.biortech.2009.06.047

Shan, T. C., Matar, M. Al, Makky, E. A., \& Ali, E. N. (2017). The use of Moringa oleifera seed as a natural coagulant for wastewater treatment and heavy metals removal. Applied Water Science, 73), 1369-1376. https://doi.org/10.1007/s13201-016-0499-8

Srawaili, N. (2008). EFEKTIFITAS BIJI KELOR (Moringa oleifera ) DALAM MENURUNKAN KEKERUHAN, KADAR ION BESI DAN MANGAN DALAM AIR. In ITB. https://doi.org/10.1007/978-94-007-2534-8_61

Widjanarko, S. B., Nugroho, A., \& Estiasih, T. (2011). Functional interaction components of protein isolates and glucomannan in food bars by FTIR and SEM studies. African Journal of Food Science, 5(1), 12-21. 